\title{
Economic Analysis of New Product (Gas for Absorption Chiller in Commercial Segment Customer)
}

\author{
Wisnu Haryadi ${ }^{1}$, Yulita Fairina Susanti ${ }^{2 *}$ \\ ${ }^{12}$ Sekolah Tinggi Manajemen Ipmi, DKI Jakarta 12750, Indonesia
}

\begin{abstract}
A B S T R A C T
The purpose of this is to evaluates a new product called GasCool that will be implemented by the company before this product launch to the costumer. This new product is a solution for the PT Perusahaan Gas Negara, Tbk ("PGN") to manage their declining revenue in commercial customer segment in the last 4 years. This study used an economic analysis to evaluates GasCool using three parameters. The parameters consist of Net Present Value, Internal Rate of Return and Payback Period. The result indicates that GasCool is feasible to be implemented and sell to the commercial segment customer. The economic analysis has shown that selling Gas Coll will generate $17.6 \%$ Internal Rate of Return and 5.5 years Payback Period. Furthermore, the Net Present Value from selling GasCool is Rp10,4 billion in 10 years of implementation and the discount rate for economic analysis is $8.2 \%$.
\end{abstract}

${ }^{*}$ Corresponding Author E-mail: yulita.susanti@ipmi.ac.id

\section{ART I CLE INF O}

Keywords:

Gas Cool,

Commercial Segment Customer,

Economic Analysis,

Financial Projection.

\section{INTRODUCTION}

\section{Gas Industry Background}

Natural gas plays a very important role in the energy mix policy in Indonesia. Natural gas is the third most used primary energy in the country after petroleum and coal. The government aggressively continues to encourage domestic natural gas utilization, including through the development of natural gas infrastructure (pipelines and LPG / CNG / LNG) to stimulate domestic industries and maintain a cleaner environment.
The use of natural gas in Indonesia only began in the early 1960s. Starting with the distribution of natural gas through a pipeline from PT Stanvac Indonesia's natural gas field in Pendopo, South Sumatra to the Pupuk Sriwidjaja factory, Pusri-1A in Palembang. In 1974 Pertamina began supplying natural gas from the field in Prabumulih, South Sumatra to Pusri II, PusriIII and Pusri IV. 
In 1974, Pertamina also began supplying natural gas from the field in the Cirebon area and from the offshore Java Sea for fertilizer, cement, ceramics and steel plants, as well as several power plants in West Java and Cilegon, Banten. In 1977, Indonesia began exporting natural gas (LNG) from the Bontang refinery and was followed in 1978 from the Arun refinery so that for several years Indonesia had become the largest LNG exporter in the world.

Currently, Indonesia is still an exporter of natural gas in the form of LNG and gas pipeline, but the supply of natural gas for export continues to decline along with the increasing domestic demand from year to year. Domestic natural gas utilization increased by an average of 9\% from 2003 to 2016. Since 2013 the volume of natural gas to meet domestic demand is greater than exports. In 2016, it is estimated that $41 \%$ of natural gas is exported from national natural gas production and next year domestic natural gas supply increases to $62 \%$. The government is committed not to extend the LNG sales contract for export which has expired.

\section{Company Background}

PT Perusahaan Gas Negara (Persero) Tbk ("PGN") initially named F L. J. N. Eindhoven \& Co. Gravenhage was established in 1859. Then, the Company was named NV. Netherland Indische Gaz Maatschapij (NV. NIGM), when the Dutch Government took control in 1950. In 1958, when the Government of the Republic of Indonesia took over the entity, the company name was changed to Badan Pengambil Alih Perusahaan-Perusahaan Listrik dan Gas (BP3LG) and then later became BPUPLN in 1961. On May 13, 1965, based on Government Regulation No. 19/1965, the entity was established as a state-owned company ("Perusahaan Negara") and became known as PN Gas. Based on Government Regulation No. 27 the year 1984, PGN was converted into a public service enterprise ("Perum") under the name PGN.

Afterward, the status of the Company was changed from a Perum to a state-owned limited liability company ("Persero") and the name was changed to PT Perusahaan Gas Negara (Persero) based on Government Regulation No. 37 the year 1994 and the Deed of Establishment No. 486 dated May 30, 1996, as notarized by Adam Kasdarmaji, S.H. The deed of establishment was approved by the Ministry of Justice of the Republic of Indonesia in its Decision Letter No. C2-7729HT.01.01. Th.96. dated May 31, 1996, and was published in The State Gazette of the Republic of Indonesia No. 8508 dated October 4, 1996, Supplement No. 80. The latest amendment of the Company's Articles of Association was based on Notarial Deed No. 23 and 24 of Notary Fathiah Helmi, S.H., dated April 6,2015 , concerning, the changes of the Company's Articles of Association and the composition of the Boards of Commissioners of the Company. The amendments were reported to and accepted by the Ministry of Laws and Human Rights of the Republic of Indonesia in its acknowledgment Letter No. AHU-AH.01.03-0928400 and No. AHUAH.01.03-0928392 dated April 29, 2015, respectively.

As a State-Owned Enterprise that engages in the natural gas downstream business, PGN conducts its business activities in the areas of natural gas transportation and trading. In the business of natural gas transportation, PGN has pipeline networks in North Sumatera, Southern part of Sumatera, Riau Islands, and the Java Sea to connect the natural gas sources location with the natural gas end-user location through the transmission pipelines mode. In the business of natural gas trading, PGN buys the natural gas from various natural gas Producers and then sells it to various natural gas end-user segments, for instance, Household Customers, Commercial Segment Customers, Industrial-Manufacture Customers, Power Plants, and Transportation Sectors, either distributed through pipelines, CNG or LNG. PGN provides an integrated natural gas infrastructure to support natural gas trading and ensures the quality of the natural gas (natural gas composition, pressure, temperature) and provide excellent services (customers contacts, disruption handling) to its end customers. PGN divides its business activities into 4 (four) principal business segments, which are:

1. Natural gas transmission businesses

2. Natural gas trading business 
3. Natural gas and oil business

4. Other businesses, i.e. telecommunication, services, constructions and maintenance of pipeline networks, building management, and financial lease align with the company's business strategy

\section{Absorption Chiller}

In the past decade, diffusion in small-scale technology has enabled the absorption of chillers to be economical-effective as well as for the size that is much needed by the market and the application of global warming and the tendency to increase energy consumption for AC purposes. The combined cycle system of natural gas (cogeneration) fuel is increasingly spreading throughout the world, especially on a small scale, because of the energy and environmental (and economic) benefits they can carry. This energy system can provide various types of energy vectors (electricity, cooling, and heat in the form of hot water and steam) with the potential energy savings of CHP and CCHP plants can also bring significant reductions in $\mathrm{CO} 2$ emissions. Moreover, it is supported by using 'cleaner' natural gas than coal or oil because of its lower carbon content. In this case, the integration of various energy sources and energy vectors is a topic of interest today. Besides, new markets are emerging worldwide to comply with the Kyoto Protocol's commitments, and Sustainability Development Goals (SDG).

\section{Commercial Segment Customer}

Service and Commercial Industry Customers are Customers who use Gas for non-commercial activities or services and/ or commercial/ commercial with Minimum Use per Month Contract above 1.000 (one thousand) m3, including government hospitals, health centers, orphanages, places of worship, government/ private educational institutions, religious institutions, government offices, social institutions and the like as well as hotels, restaurants/ restaurants, private hospitals, private offices, shops/ shophouses/ offices/ markets/ malls/ supermarkets, SPBBG/ CNG, traders/ area managers and similar commercial activities.

\section{LITERATURE REVIEW}

\section{Capital Budgeting}

When we start the new project, we have to consider the feasibility of that project. Many parameters that can define the feasibility of the new project. Another thing that important when we will start the new project is capital budgeting of new project itself. According to Ehrhardt (2011), capital budgeting is perhaps the most important task faced by financial managers and their staffs. Capital budgeting can define what the strategic direction for the company is. Before the project run by the company or even before the product or service sell or offer to the customer, it must be started with the capital budgeting. The result for capital budgeting will impact the longterm period, not for a short-term period. Mistakes in making capital budgeting will make to the negative financial impact for the company.

Capital budgeting requires many steps, but at the end of it, the objective is to simply look for projects that meet one criterion: they are worth more than they cost (Mark K, 2014). By this explanation, capital budgeting is an important way to choose the project which will give the benefit and can be implemented by the company. There are several steps that the company should run to define what project will be implemented. The important key is, that project gives more revenue compared with the cost spent.

There are several parameters that we should consider in developing capital budgeting of new projects that can be used to screening the new project whether we accept or reject. Net Present Value, Internal Rate of Return, Payback Period is some important parameters that we have to analyze before we accept the project.

\section{Economic Analysis}

Based on a book wrote by McAafee (2009), economics studies the allocation of scarce resources among people-examining what goods and services wind up in the hands of which people. Economic analysis is used in many situations. When British Petroleum sets the price for its Alaskan crude oil, it uses an estimated 
demand model, both for gasoline consumers and also for the refineries to which BP sells. The demand for oil by refineries is governed by a complex economic model used by the refineries and BP estimates the demand by refineries by estimating the economic model used by refineries. Economic analysis was used by experts in the antitrust suit brought by the U.S. Department of Justice both to understand Microsoft's incentive to foreclose (eliminate from the market) rival Netscape and consumer behavior in the face of alleged foreclosure. Stock market analysts use economic models to forecast the profits of companies to predict the price of their stocks. When the government forecasts the budget deficit or considers a change in environmental regulations, it uses a variety of economic models.

As explained by Erickson (1996), starting a new business involves many steps. The first is to develop an economic analysis to determine whether there will be a profit or loss before starting production. If there is a projected profit based on the best available information, then a business plan should be developed. There are many plans available that can be used as guides. A good place to obtain assistance is one of the Small Business Development Centers located throughout the state. Starting a Home-Based Business is a very useful guide. It discusses ways for the business person to determine where the company is, where it wants to be, and how it plans to get there. A person can also register the business at the "First Stop Clearing house" within the Department of Commerce, which can provide answers concerning legal structure, employment, taxes, licensing, and some federal requirements.

\section{Financial Planning}

According to Ehrhardt (2011), the financial planning process generally involves five steps. The first step is the firm forecasts financial statements under alternative versions of the operating plan to analyze the effects of different operating procedures on projected profits and financial ratios. The second step is to determines the amount of capital that will be needed to support the plan. It finds out how much the new assets needed to achieve the target sales will cost since, without adequate capital, the plan obviously cannot be realized. Next, the third step is firm forecasts the funds that will be generated internally. If internal funds are insufficient to cover the required new investment, then it must identify sources from which the required external capital can be raised, taking account of any constraints due to bond covenants that limit its debt ratio and other financial ratios. Market conditions must also be recognized.

The fourth step is, the firm establishes a performance-based management compensation system that rewards employees for creating shareholder wealth. The emphasis here should be on the long run, not on profits over the next few quarters or even years. A failure in this area was perhaps the most important factor leading to the worldwide financial and economic crisis that hit in 2008 and 2009. Finally, the last step is management must monitor operations after implementing the plan to spot any deviations and then take corrective actions. Computer software is helping greatly here, and it's changing the way companies do business. In particular, corporate information systems are reducing the need for "middle managers" and flattening firms' management structures. Those explanations above basically the steps that we must fulfill in making financial planning or financial projection especially in developing the new product before it sells to the customer.

\section{RESEARCH METHODS}

\section{Net Present Value}

Net Present Value is the sum of the present values of each of the cash flows (positive as well as negative) that occurs over the life of the project (Damodaran, 2014). The general formulation of the Net Present Value rule is as follows:

$$
\begin{array}{ll}
\text { NPV of project }=\sum_{\substack{t=1 \\
\text { Figure 1. Net Present Value }}}^{n} \frac{C F_{t}}{(1+r)^{t}}-\text { Initial Investment } \\
\text { Where: } \\
\begin{array}{ll}
C F_{\mathrm{t}} & =\text { Cash flow in period t } \\
\mathrm{r} & =\text { Discount Rate } \\
\mathrm{n} & =\text { Life of project }
\end{array}
\end{array}
$$


For the example, below is the small project that has the first investment of $\$ 1.000 .000 .000$ and the cash that will be expected from that project is $\$ 300.000 .000$ in the first year, $\$ 400.000 .000$ in the second year, $\$ 500.000 .000$ in the third year and $\$ 600.000 .000$ in the fourth year. The discount rate assumption for this example is $12 \%$ and the Net Present Value for his project is described in the below figure.

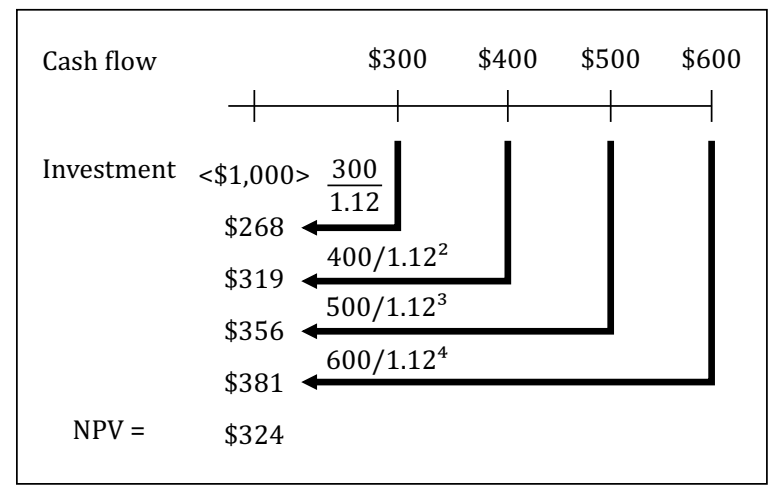

Figure 2. Net Present Value

The Net Present Value of the above example is $\$ 324$ million. Furthermore, we can define and decide the result of Net Present Value with the following condition:

a. If the Net Present Value more than 0, we can accept the project

b. If the Net Present Value below than 0, we can reject the project

The example of the project above resulted in the Net Present Value above or more than 0 , so we can consider accepting the project.

\section{Internal rate of return}

The internal rate of return is the second parameters that we have to consider before running the project. In general terms, the Internal Rate of Return is that the discount rate that makes the Net Present Value of a project equal to 0 (Damodaran, 2014). We can get the Internal Rate of Return of the project by calculating in two alternatives, there are based on the cost of capital and based on the cost of equity. And the rules relating to the result of the Internal Rate of Return of the project are:

a. If the Internal Rate of Return more than the cost of capital or cost of equity, we can consider accepting the project

b. If the Internal Rate of Return below than cost of capital or cost of equity, we can consider rejecting the project

The Internal Rate of Return is defined as the discount rate that equates the present value of a project's expected cash inflows to the present value of the project costs: PV (Inflows) - PV (Investment costs), or, equivalently, the Internal Rate of Return is the rate that forces the Net Present Value to equal zero (Ehrhardt, 2011). It means the Internal Rate of Return is the number generally in percentage (\%) that will make the Met Present Value equal to zero. The higher the Internal Rate of Return of the project is will result in a better situation.

$$
C F_{0}+\frac{C F_{1}}{(1+I R R)^{1}}+\frac{C F_{2}}{(1+I R R)^{2}}+\cdots+\frac{C F_{\mathrm{n}}}{(1+I R R)^{n}}=0
$$

$$
\mathrm{NPV}=\sum_{t=0}^{n} \frac{C F_{t}}{(1+I R R)^{t}}=0
$$

Figure 3. Internal Rate Return

Where:

$C F_{\mathrm{t}} \quad=$ Cash flow in period $\mathrm{t}$

IRR = Internal Rate of Return

$\mathrm{n} \quad=$ Life of project

\section{Payback Period}

The payback on a project is a measure of how quickly the cash flows generated by the project cover the initial investment (Damodaran, 2014). Below is the example of the cash flows generated by the project in a certain period.

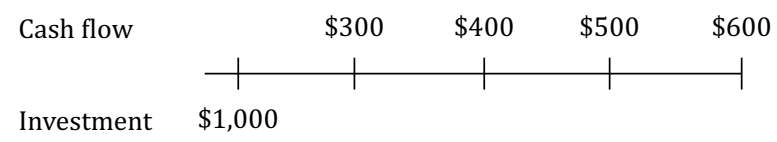

Figure 4. Payback Period

By looking at the cash flows generated in the above figure, the payback period of that project is fall in between year two and year. Considering the investment is $\$ 1000$, the cash flows of that project can cover the cost of investment after the second year and before the third year, since between that periods, the cumulated cash flows 
in the range between $\$ 700$ and $\$ 1200$. So approximately after 2.6 years the investment already covered from cash flows generated.

Table 1. Cash Flow Generated

\begin{tabular}{|c|c|c|}
\hline Year & Cash Flow in Year & Cumulated Cash Flow \\
\hline 0 & $-\$ 1.150 .000$ & \\
\hline 1 & $\$ 340.000$ & $-\$ 810.000$ \\
\hline 2 & $\$ 415.000$ & $-\$ 395.000$ \\
\hline 3 & $\$ 446.500$ & $\$ 51.500$ \\
\hline 4 & $\$ 720.730$ & $\$ 772.300$ \\
\hline
\end{tabular}

According to the table 1, the project will need an investment cost of $\$ 1.150 .000$. In the first year, the project will generate cash flows of $\$ 340.000$, in the second year will generate cash flows of $\$ 415.000$, in the third year will generate cash flows of $\$ 446.000$ and fourth year will be generated cash flows of $\$ 720.730$. Based on that cash flows generated, the unrecovered cost of investment in the first year is $\$ 810.000$. We can get this number by subtracting the investment cost with the cash flow generated in the first year. Furthermore, the unrecovered cost of investment in the second year is $\$ 395.000$. In the third year, the accumulated cash flow generated already fully covered the investment cost and resulted in a positive number of $\$ 51.500$. So, the payback period is fall between the second and third year of the project implementation. Using the below equation, we can get the payback for the project.

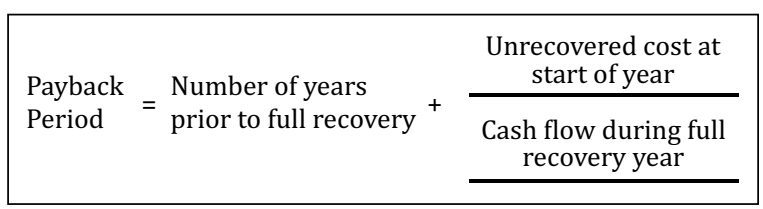

Figure 5. Payback Period

\section{RESULTS AND DISCUSSION}

\section{Product Tariff}

Our product GasCool, Gas for absorption chiller (air conditioning and water heater). Before we explain the financial analysis of product implementation, the important thing that we have to define is how much the tariff also the tariff structure of the product. The tariff structure consists of capital expenditure, gas cost, operational expenditure, tax, and return/margin.

The valuation of 1 chiller can described in below figure:

\begin{tabular}{|c|c|c|c|c|c|c|c|c|c|c|}
\hline & 2018 & 2019 & 2020 & 2021 & 2022 & 2023 & 2024 & 2025 & 2026 & 2027 \\
\hline \multicolumn{11}{|l|}{ VALUATION } \\
\hline $\begin{array}{l}\text { EBITDA } \\
\text { Interest Expense }\end{array}$ & $\begin{array}{l}1,434 \\
(319)\end{array}$ & $\begin{array}{l}1,376 \\
\end{array}$ & $\begin{array}{l}1,329 \\
(219)\end{array}$ & $\begin{array}{l}1,257 \\
(139)\end{array}$ & $\begin{array}{r}1,196 \\
(60)\end{array}$ & 1,133 & 1,080 & 1,003 & 935 & 877 \\
\hline Tax & (152) & (143) & (151) & (153) & $(158)$ & $(157)$ & $(144)$ & $(124)$ & $(107)$ & (93) \\
\hline Capex & $(5,054)$ & - & - & - & - & - & - & - & - & - \\
\hline Free Cash Flow (IDR thousand) & $(4,092)$ & 934 & 958 & 965 & 979 & 976 & 936 & 878 & 828 & 784 \\
\hline & $-4,092$ & $-3,157$ & $-2,199$ & $-1,234$ & -255 & 721 & 1,657 & 2,535 & 3,363 & 4,147 \\
\hline Payback Period & 0.00 & 0.00 & 0.00 & 0.00 & 0.00 & 5.26 & 0.00 & 0.00 & 0.00 & 0.00 \\
\hline
\end{tabular}

\section{VALUE @Year 1}

WACC Calculation Cost of Equity (\%) Equity (IDR)

Cost of Debt (\%) Debt (IDR)

Debt + Equity (IDR)

$\begin{array}{r}\hline 12.06 \% \\ 1,516,200,000 \\ 6.67 \% \\ 3,537,800,000 \\ 5,054,000,000 \\ \hline \mathbf{8 . 2 8} \% \\ \hline \\ \hline 17 \% \\ \hline 1597 \\ \hline 1,497 \\ \hline\end{array}$

\begin{tabular}{lc}
\hline WACC (\%) & $\mathbf{8 . 2 8 \%}$ \\
IRR Project & $17 \%$ \\
Tariff (Rp/TR) & 1597 \\
NPV (Rp Billion) & 1,497 \\
\hline
\end{tabular}


Using 1 chiller as a base of price calculation and 10-year financial projection the tariff of this product is $\mathrm{Rp} 1.597 / \mathrm{TR}$ and the structures are:
a. Capital Expenditure
: Rp199/TR
b. Gas Cost
: Rp932/TR
c. Operational Expenditure
:Rp100/TR
d. Tax
: Rp60/TR
e. Return / Margin
: Rp306/TR

Total

: Rp1.597/TR

\section{Customer Benefit}

Furthermore, we have to define the benefit usage of this product in terms of the customer perspective. In the customer perspective, the usage of this product will reduce the cost of air conditioning up to $14.6 \%$ or equivalent to $\mathrm{Rp} 707$ million if compare with the electrical regular chiller usage. The calculation is described in the table 2. It explains the comparison between electric regular chiller and gas absorption chiller.

Table 2. Operating Cost Comparison

\begin{tabular}{|c|c|c|c|}
\hline No & Items & $\begin{array}{c}\text { Electrical } \\
\text { Regular Chiller }\end{array}$ & $\begin{array}{l}\text { BROAD Absorption } \\
\text { Chiller (Cooling Only) }\end{array}$ \\
\hline \multirow{5}{*}{1.} & Cooling load (kW) & 1744 & 1744 \\
\hline & Cooling energy resource & Electricity & Electricity \\
\hline & Daily operation hours & 14 & 14 \\
\hline & Operation days & 365 & 365 \\
\hline & COP & 4.25 & 1.42 \\
\hline \multirow{9}{*}{2.} & \multicolumn{3}{|c|}{ Operation Cost Calculation - Electricity } \\
\hline & Total Electrical Consumption Chiller (kW/h) & 410 & 10 \\
\hline & Electricity Use/Day (kW) & $5.476,364235$ & 138.6 \\
\hline & Electricity Use/Year (kW) & 2.097 .423 & 50.589 \\
\hline & Electricity price Rp/kW.h & 1.761 & \\
\hline & Electric Cost/Day & $10.121 .047,85$ & $244.115,61$ \\
\hline & Electric Cost/Year & Rp3.694.182.466 & Rp89.102.199 \\
\hline & Total Electricity Cost (Rp/Year) & Rp3.694.182.466 & Rp89.102.199 \\
\hline & Difference Total Electricity Cost (Rp/Year) & & $\operatorname{Rp}(3.605 .080 .267)$ \\
\hline \multirow{7}{*}{3.} & \multicolumn{3}{|c|}{ Operation Cost Calculation - Natural Gas } \\
\hline & Gas Consumption (M3/Hours) & - & 110 \\
\hline & Gas Consumption (M3/Year) & - & 562,258 \\
\hline & Gas Price (Rp/M3) & 4.200 & 4.200 \\
\hline & Gas Consumption (Rp/Hours) & - & 462,130 \\
\hline & Total Gas Consumption (Rp/Year) & - & - \\
\hline & Difference Total Gas Consumption (Rp/Year) & - & - \\
\hline \multirow{5}{*}{4.} & \multicolumn{3}{|c|}{ Operation Cost Calculation - Chiller System } \\
\hline & TR Usage (TR/Year) & 2.534 .560 & 2.534 .560 \\
\hline & Chiller System Price (Rp/TR) & Rp453,59 & Rp1.597 \\
\hline & Total Chiller Cost (Rp/Year) & Rp1.149.663.119 & Rp4.046.802.908 \\
\hline & Difference Total Chiller Cost (Rp/Year) & - & Rp2.897.139.789 \\
\hline \multirow{4}{*}{5.} & \multicolumn{3}{|c|}{ Cost Calculation } \\
\hline & Total Cost (Rp/Year) & Rp4.843.845.585 & Rp4.135.905.107 \\
\hline & Difference Total Cost (Rp/Year) & - & (707.940.479) \\
\hline & $\%$ & \multicolumn{2}{|c|}{$-14.6 \%$} \\
\hline
\end{tabular}


As we can see, the total cost that customer have to spent per year if they use electric regular chiller is Rp4.8 billion per year consist of Rp3.7 billion for electric cost and Rp1.1 billion for electric chiller cost itself including maintenance cost while gas, when the customer use absorption chiller, the total cost that customer have to spend per year is Rp4.1 billion per year which consist of Rp0.9 billion for electric cost and Rp4 billion for absorption chiller cost itself. So, there is Rp707 saving cost if customer use absorption chiller. This condition will help the sales team when they want to sell this product. Since the cost saving is very dependent to the electric cost define by PLN, so this product is competitive compare with electric chiller if electric cost above Rp1.180/Kwh.

Assumption:

a. Cost of absorption chiller utilization Rp1.597/TR

b. Chiller Capacity 495 TR

c. Volume and electricity reference source from Broad Manual Book

d. Electric cost based on PLN Tariff Rp1.467/Kwh

In the current condition, as explained in the figure 7 , the customer still can enjoy the costsaving if the electric cost is above Rp1.180/kwh and if the electric cost will increase in the future, the cost-saving that customer will get increases also.
The sensitivity analysis of the electric cost described in figure 7:

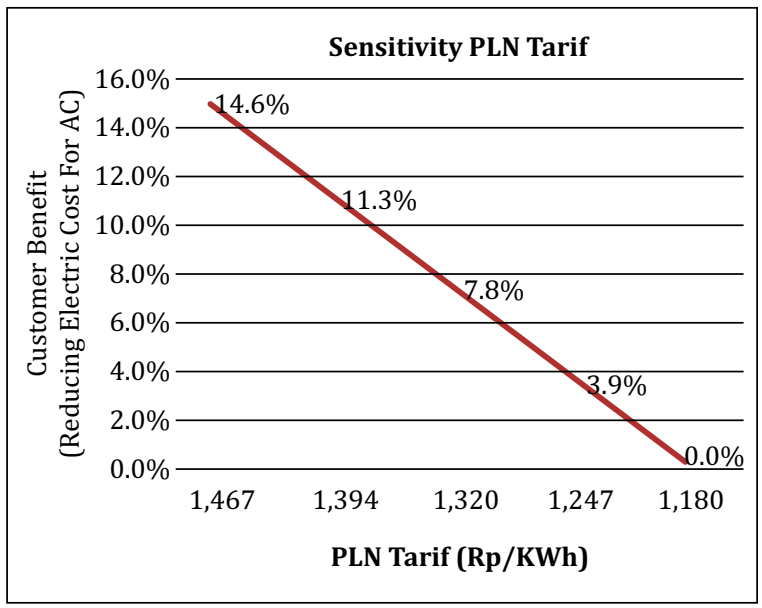

Figure 7. Sensitivity PLN Tariff

\section{Financial Projection}

Using the 10 years financial projection and with sales forecast also, by implementing this project, the company will get additional revenue Rp28.1 billion in the first-year implementation with 5 operating chillers. On the other hand, since absorption chiller uses gas to operate, there is additional revenue in gas consumption for the company Rp16.5 billion in the first year. This Internal Rate of Return of this project is $17.6 \%$ with the payback period is 5.5 years. The detail calculation of the financial projection is reflected in the figure 8,9 and 10 (in Rp Million).

\begin{tabular}{|c|c|c|c|c|c|c|c|c|c|c|}
\hline INCOME STATEMENT & 2019 & 2020 & 2021 & 2022 & 2023 & 2024 & 2025 & 2026 & 2027 & 2028 \\
\hline Volume & $17,598,427$ & $21,759,181$ & $26,930,323$ & $33,363,247$ & $41,373,273$ & $51,356,222$ & $63,809,364$ & $79,357,910$ & $98,788,541$ & $123,091,866$ \\
\hline Tarrif & 1,597 & 1,597 & 1,597 & 1,597 & 1,597 & 1,597 & 1,597 & 1,597 & 1,597 & 1,597 \\
\hline Revenue & 28,104 & 34,748 & 43,006 & 53,279 & 66,071 & 82,013 & 101,900 & 126,730 & 157,760 & 196,571 \\
\hline Gas Purchase & $(16,571)$ & $(20,899)$ & $(26,383)$ & $(33,339)$ & $(42,170)$ & $(53,391)$ & $(67,665)$ & $(85,836)$ & $(108,990)$ & $(138,519)$ \\
\hline Operating Expense & $(1,516)$ & $(1,840)$ & $(2,439)$ & $(3,062)$ & $(3,710)$ & $(4,647)$ & $(5,884)$ & $(7,433)$ & $(9,045)$ & $(11,509)$ \\
\hline Depreciation & $(3,032)$ & $(6,065)$ & $(9,097)$ & $(12,130)$ & $(15,162)$ & $(18,194)$ & $(21,227)$ & $(24,259)$ & $(27,292)$ & $(30,324)$ \\
\hline Total Operating Expense & $(21,120)$ & $(28,803)$ & $(37,919)$ & $(48,530)$ & $(61,042)$ & $(76,233)$ & $(94,776)$ & $(117,529)$ & $(145,326)$ & $(180,352)$ \\
\hline Operating Profit & 6,984 & 5,945 & 5,088 & 4,749 & 5,029 & 5,780 & 7,124 & 9,202 & 12,434 & 16,219 \\
\hline EBITDA & 10,016 & 12,010 & 14,185 & 16,879 & 20,191 & 23,975 & 28,351 & 33,461 & 39,725 & 46,543 \\
\hline \multicolumn{11}{|l|}{ Other income/expense } \\
\hline \multicolumn{11}{|l|}{ Other income/expense } \\
\hline Total & $(1,913)$ & $(1,793)$ & $(1,314)$ & $(836)$ & $(358)$ & - & - & - & - & - \\
\hline Profit Before Tax & 5,071 & 4,152 & 3,773 & 3,913 & 4,672 & 5,780 & 7,124 & 9,202 & 12,434 & 16,219 \\
\hline Tax Expense & $(1,268)$ & $(1,038)$ & (943) & (978) & $(1,168)$ & $(1,445)$ & $(1,781)$ & $(2,300)$ & $(3,108)$ & $(4,055)$ \\
\hline Net Income & 3,803 & 3,114 & 2,830 & 2,935 & 3,504 & 4,335 & 5,343 & 6,901 & 9,325 & 12,164 \\
\hline
\end{tabular}

Figure 8. Financial Projection (1) 
BALANCE SHEET Current Assets

Cash

Receivable

Other

Total

Non Current Assets

Fixed Assets- Net

Carrying Amount

Accumulated depreciation

Other

Total Non Current Assets

Total Assets

LIABILITIES

Current Liabilities

Trade Payable

Other Payable

Total

Non Current Liabilities

Long Term Loan

Other

Tota

Total Liabilities

Shareholder Equity

Share stock

Retained Earning

current earning

dividen

Total Shareholder Equity

Total Liabilities and Equity

Cash Flow Statemen

Cash from Operation

Cash Receipt from Customer

Cash Paid To Supplier

Operational Expense

Interest Expense

Tax Expense

Others Expense

Total

Cash from Investing

Fixed Assets

Other

Cash from Financin

proceed from borrowing

loan payment

additional shares

dividen payment

Total

Net Cash

Beginning balance

Ending Balance

\begin{tabular}{rrrrr|r|r|r|r|r|r|}
\hline $\mathbf{2 0 1 9}$ & $\mathbf{2 0 2 0}$ & $\mathbf{2 0 2 1}$ & $\mathbf{2 0 2 2}$ & $\mathbf{2 0 2 3}$ & $\mathbf{2 0 2 4}$ & $\mathbf{2 0 2 5}$ & $\mathbf{2 0 2 6}$ & $\mathbf{2 0 2 7}$ & $\mathbf{2 0 2 8}$ \\
\hline 6,835 & 5,654 & 2,166 & 1,816 & 5,067 & 12,435 & 18,789 & 24,679 & 36,026 & 38,083 \\
- & - & - & - & - & - & - & - & - & - \\
\hline 6,835 & 5,654 & 2,166 & 1,816 & 5,067 & 12,435 & 18,789 & 24,679 & 36,026 & 38,083 \\
\hline & & & & & & & & \\
27,292 & 26,281 & 27,292 & 25,270 & 20,216 & 17,184 & 16,173 & 17,184 & 15,162 & 25,270 \\
30,324 & 35,378 & 45,486 & 55,594 & 65,702 & 80,864 & 101,080 & 126,350 & 151,620 & 192,052 \\
$(3,032)$ & $(9,097)$ & $(18,194)$ & $(30,324)$ & $(45,486)$ & $(63,680)$ & $(84,907)$ & $(109,166)$ & $(136,458)$ & $(166,782)$ \\
& & & & & & & & \\
\hline 27,292 & 26,281 & 27,292 & 25,270 & 20,216 & 17,184 & 16,173 & 17,184 & 15,162 & 25,270 \\
\hline 34,127 & 31,935 & 29,458 & 27,086 & 25,283 & 29,618 & 34,961 & 41,863 & 51,188 & 63,353 \\
\hline
\end{tabular}

\begin{tabular}{|c|c|c|c|c|c|c|c|c|c|}
\hline- & - & - & - & - & - & - & - & - & - \\
\hline 21,227 & 15,920 & 10,613 & 5,307 & - & - & - & - & - & - \\
\hline 21,227 & 15,920 & 10,613 & 5,307 & - & - & - & - & - & - \\
\hline 21,227 & 15,920 & 10,613 & 5,307 & - & - & - & - & - & - \\
\hline 9,097 & 9,097 & 9,097 & 9,097 & 9,097 & 9,097 & 9,097 & 9,097 & 9,097 & 9,097 \\
\hline 3,803 & 6,917 & 9,747 & 12,682 & 16,186 & 20,521 & 25,864 & 32,766 & 42,091 & 54,255 \\
\hline 3,803 & 3,114 & 2,830 & 2,935 & 3,504 & 4,335 & 5,343 & 6,901 & 9,325 & 12,164 \\
\hline 12,900 & 16,015 & 18,844 & 21,779 & 25,283 & 29,618 & 34,961 & 41,863 & 51,188 & 63,353 \\
\hline 34,127 & 31,935 & 29,458 & 27,086 & 25,283 & 29,618 & 34,961 & 41,863 & 51,188 & 63,353 \\
\hline
\end{tabular}

Figure 9. Financial Projection (2)

\begin{tabular}{|c|c|c|c|c|c|c|c|c|c|}
\hline 2019 & 2020 & 2021 & 2022 & 2023 & 2024 & 2025 & 2026 & 2027 & 2028 \\
\hline 28,104 & 34,748 & 43,006 & 53,279 & 66,071 & 82,013 & 101,900 & 126,730 & 157,760 & 196,571 \\
\hline$(16,571)$ & $(20,899)$ & $(26,383)$ & $(33,339)$ & $(42,170)$ & $(53,391)$ & $(67,665)$ & $(85,836)$ & $(108,990)$ & $(138,519)$ \\
\hline$(1,516)$ & $(1,840)$ & $(2,439)$ & $(3,062)$ & $(3,710)$ & $(4,647)$ & $(5,884)$ & $(7,433)$ & $(9,045)$ & $(11,509)$ \\
\hline$(1,913)$ & $(1,793)$ & $(1,314)$ & (836) & (358) & - & - & - & - & - \\
\hline$(1,268)$ & $(1,038)$ & (943) & (978) & $(1,168)$ & $(1,445)$ & $(1,781)$ & $(2,300)$ & $(3,108)$ & $(4,055)$ \\
\hline 6,835 & 9,179 & 11,927 & 15,064 & 18,666 & 22,530 & 26,570 & 31,161 & 36,617 & 42,488 \\
\hline$(30,324)$ & $(5,054)$ & $(10,108)$ & $(10,108)$ & $(10,108)$ & $(15,162)$ & $(20,216)$ & $(25,270)$ & $(25,270)$ & $(40,432)$ \\
\hline$(30,324)$ & $(5,054)$ & $(10,108)$ & $(10,108)$ & $(10,108)$ & $(15,162)$ & $(20,216)$ & $(25,270)$ & $(25,270)$ & $(40,432)$ \\
\hline
\end{tabular}

\begin{tabular}{|c|c|c|c|c|c|c|c|c|c|}
\hline $\begin{array}{r}21,227 \\
-\end{array}$ & $(5,307)$ & $(5,307)$ & $(5,307)$ & $(5,307)$ & - & - & - & - & - \\
\hline 30,324 & $(5,307)$ & $(5,307)$ & $(5,307)$ & $(5,307)$ & - & - & - & - & 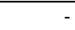 \\
\hline 6,835 & $(1,182)$ & $(3,488)$ & (350) & 3,251 & 7,368 & 6,354 & 5,891 & 11,347 & 2,056 \\
\hline- & 6,835 & 5,654 & 2,166 & 1,816 & 5,067 & 12,435 & 18,789 & 24,679 & 36,026 \\
\hline 6,835 & 5,654 & 2,166 & 1,816 & 5,067 & 12,435 & 18,789 & 24,679 & 36,026 & 38,083 \\
\hline
\end{tabular}

Figure 10. Financial Projection (3) 
Moreover, for the detail calculation of the Internal Rate of Return and Payback Period is explained in figure 11. Meanwhile, another thing that we have to analyze is about the sensitivity analysis relating to the sales forecast of this project. We use $90 \%$ until $110 \%$ of sales forecast and what will the impact for the Revenue, EBITDA and Net Income, IRR and also payback period in 10 years financial projection. The details are explained in the figure 12 .

\begin{tabular}{|llllllllll}
2018 & 2019 & 2020 & 2021 & 2022 & 2023 & 2024 & 2025 & 2026 & 2027
\end{tabular}

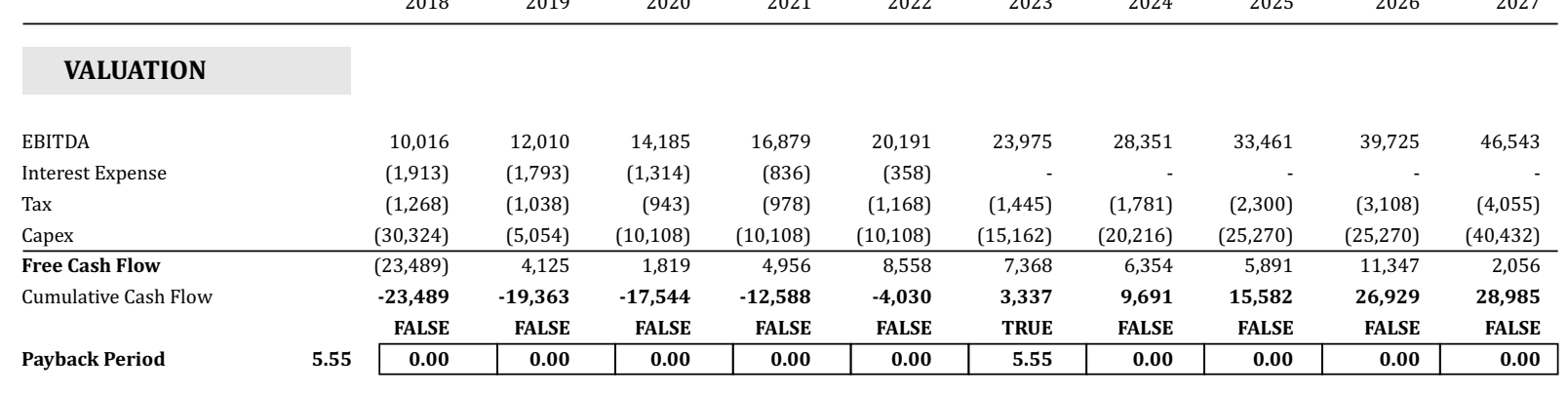

\section{VALUE @Year 1}

\begin{tabular}{lr} 
WACC Calculation \\
Cost of Equity (\%) \\
Equity (IDR) & $12.06 \%$ \\
Cost of Debt (\%) & $6.67 \%$ \\
Debt (IDR) & $21,226,800,000$ \\
Debt + Equity (IDR) & $30,324,000,000$ \\
\hline WACC (\%) & $8.28 \%$ \\
\hline \multirow{2}{*}{ IRR Project } & $17.61 \%$ \\
\hline & \\
\hline & $10,410.55$ \\
\hline
\end{tabular}

Figure 11. Payback Period and Internal Rate Return

\begin{tabular}{|c|c|c|c|c|c|c|c|c|c|c|c|c|}
\hline $\begin{array}{l}\text { Volume } \\
\text { (Projected } \\
\text { Volume) }\end{array}$ & 2019 & 2020 & 2021 & 2022 & 2023 & 2024 & 2025 & 2026 & 2027 & 2028 & IRR & $\begin{array}{c}\text { Payback } \\
\text { Period } \\
\text { (Year) }\end{array}$ \\
\hline $90 \%$ & $\begin{array}{l}\text { Revenue } \\
25,293\end{array}$ & 31,273 & 38,706 & 47,951 & 59,464 & 73,812 & 91,710 & 114,057 & 141,984 & 176,914 & $4.6 \%$ & 7.83 \\
\hline $95 \%$ & 26,699 & 33,011 & 40,856 & 50,615 & 62,767 & 77,913 & 96,805 & 120,394 & 149,872 & 186,743 & $11.9 \%$ & 6.26 \\
\hline $100 \%$ & 28,104 & 34,748 & 43,006 & 53,279 & 66,071 & 82,013 & 01,900 & 126,730 & 157,760 & 196,571 & $17.6 \%$ & 5.50 \\
\hline $105 \%$ & 29,509 & 36,486 & 45,157 & 55,943 & 69,375 & 86,114 & 06,995 & 133,067 & 165,648 & 206,400 & $22.6 \%$ & 5.10 \\
\hline $110 \%$ & 30,914 & 38,223 & 47,307 & 58,607 & 72,678 & 90,215 & 12,090 & 139,403 & 173,536 & 216,228 & $27.2 \%$ & 4.77 \\
\hline $90 \%$ & $\begin{array}{r}\text { EBITDA } \\
8,863\end{array}$ & 10,625 & 12,522 & 14,885 & 17,801 & 21,113 & 24,928 & 29,372 & 34,848 & 40,738 & $4.6 \%$ & 7.83 \\
\hline $95 \%$ & 9,440 & 11,317 & 13,354 & 15,882 & 18,996 & 22,544 & 26,639 & 31,416 & 37,287 & 43,641 & $11.9 \%$ & 6.26 \\
\hline $100 \%$ & 10,016 & 12,010 & 14,185 & 16,879 & 20,191 & 23,975 & 28,351 & 33,461 & 39,725 & 46,543 & $17.6 \%$ & 5.50 \\
\hline $105 \%$ & 10,593 & 12,702 & 15,016 & 17,876 & 21,386 & 25,406 & 30,063 & 35,506 & 42,164 & 49,446 & $22.6 \%$ & 5.10 \\
\hline $110 \%$ & 11,170 & 13,395 & 15,847 & 18,873 & 22,581 & 26,837 & 31,775 & 37,550 & 44,602 & 52,349 & $27.2 \%$ & 4.77 \\
\hline & Net Income & & & & & & & & & & & \\
\hline $90 \%$ & 2,938 & 2,076 & 1,448 & 1,177 & 1,491 & 2,037 & 26,691 & 3,809 & 5,668 & 7,811 & $4.6 \%$ & 7.83 \\
\hline $95 \%$ & 3,371 & 2,595 & 2,206 & 2,119 & 2,544 & 3,216 & 4,030 & 5,355 & 7,497 & 9,988 & $11.9 \%$ & 6.26 \\
\hline $100 \%$ & 3,803 & 3,114 & 2,830 & 2,935 & 3,504 & 4,335 & 5,343 & 6,901 & 9,325 & 12,164 & $17.6 \%$ & 5.50 \\
\hline $105 \%$ & 4,236 & 3,634 & 3,453 & 3,683 & 4,400 & 5,409 & 6,627 & 8,435 & 11,154 & 14,341 & $22.6 \%$ & 5.10 \\
\hline $110 \%$ & 4,668 & 4,153 & 4,077 & 4,430 & 5,296 & 6,482 & 7,911 & 9,968 & 12,983 & 16,518 & $27.2 \%$ & 4.77 \\
\hline
\end{tabular}

Figure 12. 10 years Financial Projection 


\section{CONCLUSION}

Based on the analysis explained in the previous chapter, GasCool is feasible to be implemented and it will generate the benefits. PGN will get $17.6 \%$ on IRR and 5.5 years payback period. PGN will get additional revenue, especially from commercial customer segment Rp28 billion in 2019 and increase to Rp196 billion in 2028 based on financial forecasting. From the additional revenue, PGN will get an additional net income Rp4 billion in 2019 and increase to 12 billion in 2019. This benefit is come from selling the product only, not including additional revenue generated from selling the gas for the GasCool.

Furthermore, Using GasCool, the customer will save electricity cost up to Rp707 million peryear for the air conditioner and Rp190 million per year for the water heater. Customer will get the benefit as mentioned above because they use less electricity to operate the absorption chiller compared to electric chiller since the electricity tariff is more expensive and historically it increases every year.

\section{RE F EREN C ES}

Damodaran, A. (2014). Applied Corporate Finance Fourth Edition. Wiley.

Ehrhardt, M. C. (2002). Corporate Finance : A Focused Approach. Cengage South-Western.

Ehrhardt, M. C. (2011). Corporate Finance: A Focus Approach. South Western Cengange Learning.

Erickson, D. (1996). Economic Analysis of a New Business. 1.

Mark K, P. (2014). Applied Corporate Finance. New York: Springer.

McAafee, P. (2009). Introduction to Economic Analysis. Saylor Foundation. 